\title{
PERSEPSI MAHASISWA AKUNTANSI DAN PRAKTISI AKUNTANSI SYARIAH TERHADAP PARADIGMA, ETIKA, DAN KOMPETENSI PRAKTISI AKUNTANSI SYARIAH
}

\begin{abstract}
This study aims to: (1) to determine the differences in perceptions between students who have and who have followed the accounting courses accounting practitioners of Islamic sharia, (2) to determine differences in perceptions between students who have not taken an accounting class accounting practitioners Islamic sharia and the practitioners Islamic accounting, and (3) to determine differences in perceptions between students who have attended courses and practitioner of Islamic accounting accounting accounting practitioners Islamic sharia.

Object of this study was the perception of students and practitioners of the Islamic accounting practitioners. In this research, the writer uses descriptive method and the T-Test using SPSS computer program. Results of data analysis and hypothesis testing is done by processing the data from the questionnaires distributed to accounting students at Sultan Agung Islamic University, School of Economics Central Java, and the State Islamic Institute Wali Songo many as 99 people and practitioners of Islamic accounting in Islamic banks City Semaranng many as 27 people.

Based on the analysis of data, it can be concluded that: (1) there are differences in perception between accounting students who have and have not been taking courses toward a paradigm of Islamic accounting, ethics, and competence of practitioners of Islamic accounting, (2) there are differences in perception between accounting students who have to take accounting courses and accounting practitioners of Islamic sharia on paradigms, ethics, and competence of practitioners of Islamic accounting, and (3) there are differences in perception between accounting students who have taken accounting courses and accounting practitioners of Islamic sharia on paradigms, ethics, and competence of practitioners of Islamic accounting..
\end{abstract}

Keywords: perception, paradigm, ethics, competence, accounting sharia.

\section{PENDAHULUAN}

Perkembangan ekonomi Islam ditandai dengan munculnya praktik-praktik ilmu akuntansi syariah seperti halnya perbankan syariah yang bermunculan secara pesat. Dalam perkembangannya, ilmu akuntansi syariah yang semula fokus pada tatanan praktik mulai merambat ke arah tatanan prinsip terutama pada pelaku maupun praktisi akuntansi yang berada di dalamnya. Berkaitan dengan prinsip, masyarakat pada masa ini telah memberikan penilaian positif terhadap lembaga keuangan syariah (Muhammad, 2002). Dengan maraknya masyarakat yang berprinsip bahwa lembaga keuangan syariah itu baik, maka akan semakin tinggi pertumbuhan lembaga-lembaga keuangan syariah di Indonesia. Oleh karena itu, sangat diperlukan sumber daya tenaga akuntansi syariah yang handal dan terpercaya dalam mengelola lembaga syariah.

Praktisi yang bekerja di lembaga keuangan syariah ini harus dapat menjamin semua transaksi keuangan dilaksanakan berdasarkan prinsip-prinsip syariah dan sejalan dengan standar akuntansi keuangan syariah. Akuntan yang taat pada prinsip-prinsip akuntansi syariah tentu memiliki kriteria-kriteria tertentu yang 
merupakan hal utama dalam kaitannya sebagai praktisi akuntansi syariah. Dalam kaitannya dengan akuntansi syariah, ilmu sosial profetik berguna dalam pengembangan di bidang akuntansi yakni sebagi petunjuk serta arahan tentang praktik akuntansi yang sesuai dengan syariah (Triyuwono, 2006: 319).

Dalam upaya pemenuhan sumber daya tenaga akuntansi syariah, mahasiswa berada pada langkah pertama dalam pembentukan sumber daya tenaga akuntansi syariah tersebut. Mahasiswa yang merupakan subjek pertama sekaligus berhubungan langsung dengan bidang keilmuan, maka mahasiswa dapat menjadi media untuk penyampaian informasi dan pembelajaran mengenai suatu persepsi. Begitu pula dengan hal yang terkait dengan akuntansi syariah dan profesi akuntansi di bidang bisnis syariah, maka mahasiswa sangat layak dijadikan sebagai objek penelitian. Jika mahasiswa telah mendapatkan pengetahuan dan pemahaman yang cukup mengenai akuntansi syariah selama di bangku kuliah, tentu mahasiswa telah memiliki gambaran ataupun persepsi mengenai praktisi akuntansi syariah. Namun, tingkat pemahaman dan penalaran mahasiswa dapat berbeda satu sama lain terutama pada mahasiswa yang telah ataupun belum mengambil mata kuliah akuntansi syariah. Akibatnya persepsi mahasiswa yang belum ataupun telah menempuh mata kuliah akuntansi syariah terhadap praktisi akuntansi syariah bisa saja berbeda satu dengan yang lainnya.

Beberapa penelitian telah dilakukan, seperti Adriansyah (2011) menemukan bahwa persepsi mahasiswa akuntansi sebagai landasan utama dalam pemenuhan tenaga profesional praktisi akuntansi syariah akan memberikan nilai dan karakteristik yang berbeda pada akuntansi syariah dalam tatanan praktik. Dalam penelitian ini ditemukan bahwa terdapat perbedaan persepsi antara mahasiswa akuntansi dan praktisi akuntansi syariah mengenai paradigma, etika dan kompetensi praktisi akuntansi syariah. Berkaitan dengan itu, Asnita dan Bandi (2007) dalam penelitiannya menemukan bahwa tidak terdapat perbedaan persepsi antara mahasiswa akuntansi yang telah ataupun yang belum menempuh mata kuliah ekonomi Islam dan persepsi akuntan pendidik mengenai karakteristik dan tujuan akuntansi Islam terhadap akuntansi konvensional.

Penelitian ini bertujuan menguji kembali penelitian Adriansyah (2011) yang meneliti persepsi mahasiswa akuntansi dan praktisi akuntansi syariah terhadap praktisi akuntansi syariah. Penelitian Adriansyah (2011) tidak berhasil membuktikan perbedaan persepsi antara mahasiswa akuntansi yang belum ataupun yang sudah menempuh mata kuliah akuntansi syariah. Penelitian ini memperluas area responden, yang meliputi 3 universitas di Semarang yang memiliki mata kuliah akuntansi syariah.

\section{TELAAH LITERATUR \& PENGEMBANGAN HIPOTESIS}

\section{Kerangka Pemikiran}

Persepsi merupakan hal yang mutlak dalam membentuk pandangan serta pemikiran dalam menganalisis suatu hal. Dalam upaya meneliti ada atau tidaknya perbedaan persepsi antara mahasiswa akuntansi dan praktisi akuntansi syariah, maka kedua objek tersebut akan dibandingkan melalui persepsi atas paradigma, etika, dan kompetensi praktisi akuntansi syariah. Dari kedua objek yang dijadikan penelitian yakni mahasiswa akuntansi dan praktisi akuntansi syariah, "praktisi akuntansi syariah" merupakan objek yang dipersepsi berdasarkan tiga sudut pandang (perspektif) seperti: paradigma, etika, dan kompetensi. 
Persepsi antara mahasiswa akuntansi yang belum dan yang telah menempuh mata kuliah akuntansi syariah terhadap paradigma, etika, dan kompetensi praktisi akuntansi syariah

Ketertarikan, kebutuhan, kepercayaan, emosi, dan ekpektasi merupakan unsur-unsur pembentukan persepsi seseorang untuk memberikan perhatian lebih terhadap objek yang akan dipersepsi (Wade dan Travis, 2008). Seseorang yang berada dalam lingkungan serta kondisi tertentu maka akan lebih mudah mempersepsikan lingkungan tersebut berdasarkan pengalaman dan pemahaman yang telah terjadi (Wispe dan Drambarean, 1953 dalam Wade dan Travis, 2008). Selain itu, objek yang akan diteliti dapat mempengaruhi apa yang diartikan, yakni dimana pribadi melihat objek tersebut berdasarkan motivasi maupun kepentingan masing-masing (Mulyana, 2010).

Mahasiswa akuntansi selaku responden yang belum dan yang telah menempuh mata kuliah akuntansi syariah diduga memiliki perbedaan persepsi terhadap praktisi akuntansi syariah. Mahasiswa yang telah menempuh mata kuliah akuntansi syariah tentu memiliki pengetahuan terkait profile praktisi akuntansi syariah, sedangkan mahasiswa akuntansi belum menempuh mata kuliah akuntansi syariah memiliki latar belakang dan pengetahuan yang berbeda pula. Oleh karena itu, latar belakang dari masing-masing lingkungan individu sangat mempengaruhi persepsi yang ditimbulkan (Rakhmat dalam Wawan dan Nurul, 2009). Berdasarkan penjelasan tersebut, maka dapat dirumuskan hipotesis sebagai berikut:

$\mathrm{H}_{1}$ : Terdapat perbedaan persepsi antara mahasiswa akuntansi yang telah dan belum menempuh mata kuliah akuntansi syariah terhadap paradigma, etika, dan kompetensi praktisi akuntansi syariah.

Persepsi antara mahasiswa akuntansi yang belum dan praktisi akuntansi syariah terhadap paradigma, etika, dan kompetensi praktisi akuntansi syariah

Mahasiswa akuntansi selaku responden yang belum menempuh mata kuliah akuntansi syariah dan praktisi akuntansi diduga memiliki perbedaan persepsi terhadap praktisi akuntansi syariah. Dengan adanya pengalaman praktisi akuntansi syariah tentu memahami standar pekerjaannya seperti prinsip-prinsip moral, etika, dan kompetensi (Tjiptohadi dalam Kartikawati, 2009). Sedangkan mahasiswa yang belum menempuh mata kuliah akuntansi syariah belum memiliki pengetahuan terkait profile praktisi akuntansi syariah, namun tentu dengan adanya perbedaan ini mahasiswa yang belum mengambil mata kuliah akuntansi syariah akan memiliki persepsi yang timbul akibat faktor psikologis (Scihffman dan Kanuk, 2004). Praktisi akuntansi syariah juga berada di dalam lingkungan dimana akuntansi syariah pada tatanan praktik berjalan. Berdasarkan penjelasan tersebut, maka dapat dirumuskan hipotesis sebagai berikut:

$\mathrm{H}_{2}$ :Terdapat perbedaan persepsi antara mahasiswa akuntansi yang belum dan praktisi akuntansi syariah terhadap paradigma, etika, dan kompetensi praktisi akuntansi syariah.

\section{Persepsi antara mahasiswa akuntansi yang telah menempuh mata kuliah akuntansi syariah dan praktisi akuntansi syariah terhadap paradigma, etika, dan kompetensi praktisi akuntansi syariah}

Mahasiswa akuntansi selaku responden yang telah menempuh mata kuliah akuntansi syariah dan praktisi akuntansi diduga memiliki perbedaan persepsi terhadap praktisi akuntansi syariah. Mahasiswa 
yang telah menempuh mata kuliah akuntansi syariah memiliki keterbatasan informasi terkait profile praktisi akuntansi syariah, maka persepsi yang dihasilkan akan memiliki cara pandang yang berbeda sebagai buah dari penginderaan kenyataan atas pengalaman yang diperolehnya di bangku perkuliahan (Gordon dalam Wawan dan Nurul, 2009). Praktisi akuntansi syariah berada dalam lingkungan dimana tatanan praktik akuntansi syariah berjalan. Mahasiswa yang telah menempuh mata kuliah akuntansi syariah tentu memiliki orientasi untuk menjadi akuntan syariah yang profesional, oleh karena itu dengan penelitian terhadap mahasiswa merupakan langkah awal untuk mengetahui sejauh mana pemahaman yang dicapai terkait hal penelitian tersebut (Jeffrey dalam Lili, Agus, Dada, dan Marwanto, 2011). Berdasarkan penjelasan tersebut, maka dapat dirumuskan hipotesis sebagai berikut:

$\mathrm{H}_{3}$ : Terdapat perbedaan persepsi antara mahasiswa akuntansi yang telah menempuh mata kuliah akuntansi syariah dan praktisi akuntansi syariah terhadap paradigma, etika, dan kompetensi praktisi akuntansi syariah.

\section{METODE PENELITIAN}

Populasi dalam penelitian ini adalah mahasiswa jurusan akuntansi Fakultas Ekonomi Universitas Islam Sultan Agung, Sekolah Tinggi Ilmu Ekonomi Bank Pemerintah Daerah Jawa Tengah, Institut Agama Islam Negeri Walisongo Semarang dan praktisi akuntansi syariah yang bekerja di lembaga keuangan syariah di wilayah Semarang. Teknik pengambilan sampel yang digunakan dalam penelitian ini adalah metode purposive sampling dimana pengambilan sampel dilakukan berdasarkan pertimbangan dan memenuhi beberapa kriteria: pertama, Fakultas ekonomi di Semarang yang telah memiliki mata kuliah akuntansi syariah. Kedua, Mahasiswa yang berada di jurusan akuntansi, minimal semester VI (enam), baik yang sudah menempuh mata kuliah akuntansi syariah maupun yang belum. Ketiga, Praktisi akuntansi syariah adalah mereka yang bekerja di lembaga keuangan syariah di Semarang. Keempat, Praktisi syariah merupakan praktisi yang berperan dalam penyusunan anggaran maupun laporan keuangan di lembaga keuangan syariah. Adapun jabatan yang dapat diduduki mulai dari pegawai biasa sampai dengan kepala bagian akuntansi, controler atau direktur keuangan.

\section{Definisi Operasional dan Pengukuran Variabel}

Persepsi didefinisikan sebagai suatu proses dengan mana individu-individu mengorganisasikan dan menafsirkan kesan indera mereka agar memberi makna pada lingkungan mereka (Rakhmat dalam Wawan dan Nurul, 2009). Praktisi akuntansi syariah dalam penelitian ini sesuai dengan yang dikemukakan Soemarso dalam Adriansyah (2011) yakni akuntan manajemen yang bekerja di lembaga keuangan atau perusahaan berbasis syariah. Akuntan manajemen adalah para akuntan yang bekerja dalam suatu perusahaan atau organisasi. Jabatan yang dapat diduduki mulai dari pegawai biasa sampai dengan kepala bagian akuntansi, controller atau direktur keuangan. Adapun tugas yang dapat dikerjakan yakni, penyusunan sistem akuntansi, penyusunan laporan akuntansi kepada pihak-pihak di luar perusahaan, penyusunan laporan akuntansi kepada pihak manajemen, penyusunan anggaran, menangani masalah perpajakan, melakukan pemeriksaan intern.

Paradigma dalam sudut pandang praktisi akuntansi syariah berada dalam perspektif Islam, yakni landasan atau tuntunan praktisi akuntansi syariah dalam bekerja maupun beraktivitas sesuai dengan syariah Islam. 
Etika merupakan keputusan dalam memilih prinsip atau nilai-nilai yang benar dan salah, baik atau buruk oleh praktisi akuntansi syariah dalam bekerja maupun beraktivitas sesuai dengan perspektif atau sudut pandang Islam. Duska dan Duska (2003: 26) mendefinisikan etika adalah segala sesuatu mengenai prinsip tingkah laku yang pada akhirnya berakhir pada kesimpulan benar atau salah, baik atau buruk antar masing-masing individu. Kompetensi merupakan suatu keahlian, mempunyai kualifikasi tertentu, berpengalaman sesuai dengan bidang keahliannya sesuai dengan standar pekerjaan yang diterapkan, serta keahlian yang wajib terdapat pada diri seorang praktisi akuntansi syariah yang dilandasi atas pengetahuan akan prinsip-prinsip moral serta etika profesi yang merujuk pada pemahaman atas standar pekerjaan yang dipersyaratkan.

\section{HASIL \& PEMBAHASAN}

Tabel 1 menjelaskan bahwa rata-rata persepsi praktisi mengenai paradigma adalah sebesar 17,15 yang berada di atas median teoritisnya yaitu 12. Hal ini menunjukkan bahwa rata-rata praktisi akuntansi syariah memiliki persepsi yang positif mengenai paradigma akuntansi syariah. Pada kelompok mahasiswa yang sudah mengambil mata kuliah Akuntansi Syariah, diperoleh rata-rata persepsi mengenai paradigma adalah sebesar 13,21. Nilai tersebut juga berada di atas median teoritisnya yaitu 12. Hal ini menunjukkan bahwa persepsi mahasiswa yang sudah mengambil mata kuliah Akuntansi Syariah mengenai paradigma cenderung positif. Pada kelompok mahasiswa yang belum mengambil mata kuliah Akuntansi Syariah, diperoleh rata-rata persepsi mengenai Paradigma adalah sebesar 15,06. Nilai tersebut juga berada di atas median teoritisnya yaitu 12. Hal ini menunjukkan bahwa persepsi mahasiswa yang belum mengambil mata kuliah Akuntansi Syariah mengenai paradigma juga cenderung positif.

Berdasarkan tabel 2 menunjukkan bahwa rata-rata persepsi praktisi mengenai etika adalah sebesar 29,70 yang berada di atas median teoritisnya yaitu 21. Hal ini berarti bahwa rata-rata praktisi akuntansi syariah memiliki persepsi yang positif mengenai etika. Pada kelompok mahasiswa yang sudah mengambil mata kuliah Akuntansi Syariah, diperoleh rata-rata persepsi mengenai Etika adalah sebesar 18,35. Nilai tersebut juga berada di bawah median teoritisnya yaitu 21. Hal ini menunjukkan bahwa persepsi mahasiswa yang sudah mengambil mata kuliah Akuntansi Syariah mengenai paradigma cenderung negatif. Pada kelompok mahasiswa yang belum mengambil mata kuliah Akuntansi Syariah, diperoleh rata-rata persepsi mengenai Etika adalah sebesar 24,87 . Nilai tersebut berada di atas median teoritisnya yaitu 21. Hal ini menunjukkan bahwa persepsi mahasiswa yang belum mengambil mata kuliah Akuntansi Syariah mengenai Etika cenderung positif.

Berdasarkan tabel 3 menunjukkan bahwa rata-rata persepsi praktisi mengenai kompetensi adalah sebesar 31,85 yang berada di atas median teoritisnya yaitu 24 . Hal ini berarti bahwa rata-rata praktisi akuntansi syariah memiliki persepsi yang positif mengenai kompetensi. Pada kelompok mahasiswa yang sudah mengambil mata kuliah Akuntansi Syariah, diperoleh rata-rata persepsi mengenai Kompetensi adalah sebesar 16,49. Nilai tersebut juga berada di bawah median teoritisnya yaitu 24. Hal ini menunjukkan bahwa persepsi mahasiswa yang sudah mengambil mata kuliah Akuntansi Syariah mengenai Kompetensi cenderung negatif. Pada kelompok mahasiswa yang belum mengambil mata kuliah Akuntansi Syariah, diperoleh rata-rata persepsi 
mengenai Kompetensi adalah sebesar 25,85. Nilai tersebut berada di atas median teoritisnya yaitu 24. Hal ini menunjukkan bahwa persepsi mahasiswa yang belum mengambil mata kuliah Akuntansi Syariah mengenai Kompetensi juga cenderung positif.

\section{Pengujian Asumsi Klasik}

Berdasarkan hasil signifikasi data menyebar sepanjang garis diagonal, hasil penelitian menunjukkan bahwa banyak dari uji distribusi variabel memiliki signifikansi di atas 0,05. Hal ini berarti bahwa masing-masing variabel berdistribusi normal.

\section{Pengujian Hipotesis}

Hipotesis 1: Perbedaan persepsi antara mahasiswa akuntansi yang belum dan yang telah menempuh mata kuliah akuntansi syariah terhadap paradigma, etika, dan kompetensi praktisi akuntansi syariah

Berdasarkan hasil perhitungan pada tabel 5 diperoleh nilai signifikasi 0,000<0,05. Hal ini dapat diartikan bahwa terdapat perbedaan persepsi antara mahasiswa yang telah dan belum menempuh mata kuliah akuntansi syariah. Hasil ini tidak sejalan dengan penelitian Adriansyah (2011), yang menyatakan terdapat perbedaan persepsi antara mahasiswa yang telah dan belum menempuh mata kuliah akuntansi syariah terhadap paradigma, etika, dan kompetensi praktisi akuntansi syariah.

Hipotesis 2: Perbedaan persepsi antara praktisi akuntansi syariah dan mahasiswa akuntansi yang belum menempuh mata kuliah akuntansi syariah terhadap paradigma, etika, dan kompetensi praktisi akuntansi syariah

Berdasarkan hasil perhitungan pada tabel 5 diperoleh nilai signifikasi 0,000<0,05. Hal ini dapat diartikan bahwa terdapat perbedaan persepsi antara praktisi akuntansi syariah dan mahasiswa yang belum menempuh mata kuliah akuntansi syariah. Hasil ini sejalan dengan penelitian Adriansyah (2011), yang menyatakan terdapat perbedaan persepsi antara praktisi akuntansi syariah dan mahasiswa yang belum menempuh mata kuliah akuntansi syariah terhadap paradigma, etika, dan kompetensi praktisi akuntansi syariah.

Hipotesis 3: Perbedaan persepsi antara praktisi akuntansi syariah dan mahasiswa akuntansi yang telah menempuh mata kuliah akuntansi syariah terhadap paradigma, etika, dan kompetensi praktisi akuntansi syariah

Berdasarkan hasil perhitungan pada tabel 5 diperoleh nilai signifikasi 0,000<0,05. Hal ini dapat diartikan bahwa terdapat perbedaan persepsi antara praktisi akuntansi syariah dan mahasiswa yang belum menempuh mata kuliah akuntansi syariah. Hasil ini sejalan dengan penelitian Adriansyah (2011), yang menyatakan terdapat perbedaan persepsi antara praktisi akuntansi syariah dan mahasiswa yang telah menempuh mata 
kuliah akuntansi syariah terhadap paradigma, etika, dan kompetensi praktisi akuntansi syariah.

\section{SIMPULAN}

Berdasarkan hasil penelitian yang telah dilakukan, maka dapat dibuat kesimpulan sebagai berikut : pertama, Terdapat perbedaan persepsi antara mahasiswa akuntansi yang belum dan yang telah mengikuti mata kuliah akuntansi syariah terhadap paradigma, etika, dan kompetensi praktisi akuntansi syariah. Kedua, Terdapat perbedaan persepsi antara mahasiswa akuntansi yang belum mengikuti mata kuliah akuntansi syariah dan praktisi akuntansi syariah terhadap paradigma, etika, dan kompetensi praktisi akuntansi syariah. Ketiga, Terdapat perbedaan persepsi antara mahasiswa akuntansi yang telah mengikuti mata kuliah akuntansi syariah dan praktisi akuntansi syariah terhadap paradigma, etika, dan kompetensi praktisi akuntansi syariah.

Penelitian ini masih membutuhkan beberapa perbaikan untuk dilakukan pada penelitian selanjutnya terkait dengan objek kajian yang sejenis dengan penelitian ini di masa mendatang, diantaranya dengan menambah beberapa variabel lain yang dapat digunakan untuk menganalisis faktor-faktor yang penyebab adanya variasi jawaban sebagian kecil responden yang penulis peroleh jawaban kuesionernya. Sampel responden juga sebaiknya lebih diperluas untuk mendapatkan keterwakilan yang lebih besar atas populasi penelitian yang diteliti. Perluasan ini dapat berupa cakupan geografis responden maupun perluasan jangkauan responden dari stakeholder terhadap penelitian yang sejenis dengan objek kajian penulis seperti dosen, nasabah dan dewan syariah..

\section{DAFTAR PUSTAKA}

Adriansyah. 2011. Persepsi Mahasiswa Akuntansi dan Praktisi Akuntansi Syariah Terhadap Praktisi Akuntansi di Indonesia. Skripsi S1, Fakultas Ekonomi Universitas Hasanuddin. Makassar.

Asnita dan Bandi. 2007. Akuntansi Islam: Persepsi Akuntan dan Calon Akuntan. SNA X Makasar.

Cravens, D.W. 1998. Pemasaran Strategis. Edisi Keempat, Jilid 2, Penerbit Erlangga. Jakarta.

Duska, Ronald F. Dan Duska, Brenda S. 2003. Accounting Ethics. Penerbit Blackwell. Australia.

Efendy, Taufiq. 2010. Pengaruh Kompetensi, Independensi, dan Motivasi Terhadap Kualitas Audit Aparat Inspektorat

Dalam Pengawasan Keuangan Daerah: Studi Empiris pada Pemerintah Kota Gorontalo. Tesis S2, Program Studi Magister Sains Akuntansi Universita Diponegoro. Semarang.

Ghozali, Imam. 2006. Aplikasi Analisis Multivariate dengan Program SPSS. Badan Penerbit Universitas Diponegoro. Semarang.

Harahap, Sofyan S. 2004. Akuntansi Islam. Penerbit Bumi Aksara. Jakarta.

Harahap, Sofyan S. 2007. Krisis Akuntansi Kapitalis Peluang Akuntansi Syariah. Penerbit Pustaka Quantum. Jakarta.

Harahap, Sofyan S. 2008. Kerangka Teori Dan Tujuan Akuntasi Syariah. Penerbit Pustaka Quantum. Jakarta. Harahap, Sofyan S. 2011. Etika Bisnis Dalam Perspektif Islam. Penerbit Salemba Empat. Jakarta. Ikatan Akuntan Indonesia. 2007. Standar Akuntansi Keuangan. Penerbit Salemba Empat. Jakarta Ikatan Akuntan Indonesia. 2008. Ujian Sertifikasi Akuntansi Syariah. Artikel. http://www.iaiglobal.or.id. Diakses 
27 Maret 2013.

Ikbal, Muhammad. 2011. Pengaruh Motivasi Terhadap Minat Mahasiswa Akuntansi Untuk Mengikuti Pendidikan PPAk: Studi Kasus Pada Mahasiswa Akuntansi Universitas Diponegoro Semarang. Skripsi S1, Fakultas Ekonomi Universitas Diponegoro. Semarang.

Kartikawati. 2009. Pengaruh Faktor-Faktor Profesionalisme Auditor dan Perilaku Difungsional Auditor Terhadap Kualitas Audit. Skripsi S1. Fakultas Ekonomi Universitas Islam Sultan Agung. Semarang.

Lili, Agus, Dadan, dan Marwanto. 2011. Pendekatan Baru Pengembangan Etika Profesi Akuntan: Anteseden Perilaku Moral Mahasiswa Akuntansi Perspektif Rest Cognitive Model. SNA XIV.

Muhammad. 2002. Penyesuaian Teori Akuntansi Syariah: Perspektif AkuntansiSosial Dan Pertanggungjawaban. Journal of Islamic Economics. Sekolah Tinggi Ilmu Syariah. Yogyakarta.

Muhammad.2002. Pengantar Akuntansi Syariah. Penerbit Salemba Empat. Jakarta.

Mulyana, Deddy. 2010. Ilmu Komunikasi Suatu Pengantar. Bandung: PT. Remaja Rosdakarya.

Nurhidayah dan Nurul. 2011. Pandangan Pemilik Badan Usaha Islam Terhadap Akuntabilitas dan Moralitas. Accounting Review, Sekolah Tinggi Ilmu Ekonomi Perbanas. Surabaya.

Peter, Paul J. dan Olson, Jerry C. 1999. “Consumer Behavior": Perilaku Konsumen dan Strategi Pemasaran, Edisi Keempat, Penerbit Erlangga. Jakarta.

Rivai dan Buchari. 2009. Islamic Economics: Ekonomi Syariah Bukan Opsi, Tetapi Solusi. Penerbit Bumi Aksara. Jakarta.

Schiffman, Leon G. and Leslie Lazar Kanuk, 2004. "Consumer Behavior". Edisi Kedelapan. Prentice Hall International Editions, New York.

Setiadi, Nugroho J. 2003. Perilaku Konsumen: Konsep dan Implikasi Untuk Strategi dan Penelitian Pemasaran. Penerbit Kencana. Jakarta.

Septian, Hariyoga dan Edy, Suprianto. 2011. Pengaruh Kecerdasan Emosional, Perilaku Belajar, dan Budaya Terhadap Tingkat Pemahaman Akuntansi dengan Kepercayaan Diri Sebagai Variabel Pemoderasi. SNA XIV Banda Aceh.

Syahatah, Husain. Dan Adh-Dhahir, Siddiq M. 2005. Transaksi dan Etika Bisnis Islam. Penerbit Visi Insani. Jakarta. Triyuwono, Iwan. 2006. Akuntansi Syariah. Penerbit Raja Grafindo Persada. Jakarta.

Wade, Carole. Dan Travis, Carol. 2008. Psikologi. Penerbit Erlangga. Jakarta.

Wawan dan Nurul. 2009. Persepsi Wajib Pajak Terhadap Sunset Policy. SNA XII. 


\section{LAMPIRAN}

\section{TABEL 1}

\section{Statistik Deskriptif}

Descriptives

Paradigma

\begin{tabular}{|c|c|c|c|c|c|c|c|c|}
\hline & \multirow{2}{*}{$\mathrm{N}$} & \multirow{2}{*}{ Mean } & \multirow{2}{*}{$\begin{array}{c}\text { Std. } \\
\text { Deviation }\end{array}$} & \multirow[b]{2}{*}{ Std. Error } & \multicolumn{2}{|c|}{$\begin{array}{l}95 \% \text { Confidence Interval } \\
\text { for Mean }\end{array}$} & \multirow{2}{*}{ Minimum } & \multirow{2}{*}{ Maximum } \\
\hline & & & & & $\begin{array}{l}\text { Lower } \\
\text { Bound }\end{array}$ & $\begin{array}{l}\text { Upper } \\
\text { Bound }\end{array}$ & & \\
\hline Praktisi & 27 & 17.1481 & 2.10683 & .40546 & 16.3147 & 17.9816 & 10.00 & 20.00 \\
\hline $\begin{array}{l}\text { Mahasiswa sdh } \\
\text { mengambil Matkul } \\
\text { AS }\end{array}$ & 51 & 13.2157 & 4.83038 & .67639 & 11.8571 & 14.5743 & 4.00 & 20.00 \\
\hline $\begin{array}{l}\text { Mahasiswa blm } \\
\text { mengambil Matkul } \\
\text { AS }\end{array}$ & 48 & 15.0625 & 2.68492 & .38753 & 14.2829 & 15.8421 & 8.00 & 20.00 \\
\hline $\begin{array}{c}\text { Total } \\
\end{array}$ & 126 & 14.7619 & 3.89960 & .34740 & 14.0743 & 15.4495 & 4.00 & 20.00 \\
\hline
\end{tabular}

\section{TABEL 2}

\section{Descriptives}

Etika

\begin{tabular}{|c|c|c|c|c|c|c|c|c|}
\hline & \multirow{2}{*}{$\mathrm{N}$} & \multirow{2}{*}{ Mean } & \multirow{2}{*}{$\begin{array}{l}\text { Std. } \\
\text { Deviation }\end{array}$} & \multirow{2}{*}{ Std. Error } & \multicolumn{2}{|c|}{$\begin{array}{l}\text { 95\% Confidence } \\
\text { Interval for Mean } \\
\end{array}$} & \multirow{2}{*}{-Minimum } & \multirow{2}{*}{ Maximum } \\
\hline & & & & & $\begin{array}{l}\text { Lower } \\
\text { Bound }\end{array}$ & $\begin{array}{l}\text { Upper } \\
\text { Bound }\end{array}$ & & \\
\hline Praktisi & 27 & 29.7037 & 2.86645 & .55165 & 28.5698 & 30.8376 & 22.00 & 35.00 \\
\hline $\begin{array}{l}\text { Mahasiswa sdh } \\
\text { mengambil Matkul AS }\end{array}$ & 51 & 18.3529 & 7.33982 & 1.02778 & 16.2886 & 20.4173 & 7.00 & 35.00 \\
\hline $\begin{array}{l}\text { Mahasiswa blm } \\
\text { mengambil Matkul AS }\end{array}$ & 48 & 24.8750 & 3.31743 & .47883 & 23.9117 & 25.8383 & 16.00 & 33.00 \\
\hline Total & 126 & 23.2698 & 6.86954 & 61199 & 22.0586 & 24.4810 & 7.00 & 35.00 \\
\hline
\end{tabular}


TABEL 3

Kompetensi

\begin{tabular}{lcccccccc}
\hline & & & & \multicolumn{5}{c}{$\begin{array}{l}95 \% \text { Confidence Interval } \\
\text { for Mean }\end{array}$} \\
& Nean & Std. Deviation & Std. Error $\begin{array}{l}\text { Lower } \\
\text { Bound }\end{array}$ & $\begin{array}{l}\text { Upper } \\
\text { Bound }\end{array}$ & Minimum Maximum \\
\hline Praktisi & 27 & 31.8519 & 3.05971 & .58884 & 30.6415 & 33.0622 & 27.00 & 40.00 \\
\hline $\begin{array}{l}\text { Mahasiswa sdh } \\
\text { mengambil Matkul AS }\end{array}$ & 51 & 16.4902 & 8.59621 & 1.20371 & 14.0725 & 18.9079 & 8.00 & 40.00 \\
\hline $\begin{array}{l}\text { Mahasiswa blm } \\
\text { mengambil Matkul AS }\end{array}$ & 48 & 25.8542 & 3.07349 & .44362 & 24.9617 & 26.7466 & 20.00 & 36.00 \\
\hline Total & 126 & 23.3492 & 8.50159 & .75738 & 21.8503 & 24.8482 & 8.00 & 40.00 \\
\hline
\end{tabular}

Sumber : Data primer yang diolah, 2013

TABEL 4

\begin{tabular}{|c|c|c|c|c|}
\hline \multicolumn{5}{|c|}{ Hasil Uji Normalitas } \\
\hline \multicolumn{5}{|c|}{ One-Sample Kolmogorov-Smirnov Test } \\
\hline & & Paradigma & Etika & Kompetensi \\
\hline $\mathrm{N}$ & & 27 & 27 & 27 \\
\hline \multirow{2}{*}{ Normal Parameters ${ }^{\mathrm{a}}$} & Mean & 17.1481 & 29.7037 & 31.8519 \\
\hline & Std. Deviation & 2.10683 & 2.86645 & 3.05971 \\
\hline \multirow{3}{*}{ Most Extreme Differences } & Absolute & .256 & .103 & .276 \\
\hline & Positive & .158 & .103 & .276 \\
\hline & Negative & -.256 & -.099 & -.102 \\
\hline Kolmogorov-Smirnov Z & & 1.329 & .537 & 1.436 \\
\hline Asymp. Sig. (2-tailed) & & .058 & .935 & .032 \\
\hline
\end{tabular}




\begin{tabular}{|c|c|c|c|c|}
\hline \multicolumn{5}{|c|}{ One-Sample Kolmogorov-Smirnov Test } \\
\hline & & Paradigma & Etika & Kompetensi \\
\hline $\mathrm{N}$ & & 51 & 51 & 51 \\
\hline \multirow[t]{2}{*}{ Normal Parameters $^{a}$} & Mean & 13.2157 & 18.3529 & 16.4902 \\
\hline & Std. Deviation & 4.83038 & 7.33982 & 8.59621 \\
\hline \multirow[t]{3}{*}{ Most Extreme Differences } & Absolute & .208 & .124 & .162 \\
\hline & Positive & .134 & .124 & .142 \\
\hline & Negative & -.208 & -.076 & -.162 \\
\hline \multicolumn{2}{|l|}{ Kolmogorov-Smirnov Z } & 1.486 & .885 & 1.154 \\
\hline \multirow{2}{*}{\multicolumn{5}{|c|}{$\begin{array}{l}\text { Asymp. Sig. (2-tailed) } \\
\text { a. Test distribution is Normal. }\end{array}$}} \\
\hline & & & & \\
\hline \multicolumn{5}{|c|}{ One-Sample Kolmogorov-Smirnov Test } \\
\hline & & Paradigma & Etika & Kompetensi \\
\hline $\mathrm{N}$ & & 48 & 48 & 48 \\
\hline \multirow[t]{2}{*}{ Normal Parameters $^{a}$} & Mean & 15.0625 & 24.8750 & 25.8542 \\
\hline & Std. Deviation & 2.68492 & 3.31743 & 3.07349 \\
\hline \multirow[t]{3}{*}{ Most Extreme Differences } & Absolute & .137 & .117 & .190 \\
\hline & Positive & .110 & .117 & .172 \\
\hline & Neqative & -.137 & -.098 & -.190 \\
\hline \multicolumn{2}{|l|}{ Kolmogorov-Smirnov Z } & .946 & .812 & 1.315 \\
\hline \multicolumn{2}{|l|}{ Asymp. Siq. (2-tailed) } & .332 & .524 & .063 \\
\hline
\end{tabular}

Sumber : Data sekunder yang diolah, 2013

TABEL 5

Hasil Uji t

\begin{tabular}{|c|c|c|c|c|c|c|}
\hline \multirow[b]{2}{*}{ Kelompok } & \multirow[b]{2}{*}{$\mathrm{N}$} & \multicolumn{5}{|c|}{$\begin{array}{l}\text { Test for Equality of Uji Beda } \\
\text { Variances }\end{array}$} \\
\hline & & $\mathrm{F}$ & Sig. & $\mathrm{T}$ & $\mathrm{df}$ & $\begin{array}{l}S \quad i \quad g \\
\text { (2-tailed) }\end{array}$ \\
\hline Paradigma $\mathrm{S}$ & 51 Equal variances assumed & 20.851 & .000 & -2.331 & 97 & .022 \\
\hline B & 48 Equal variances not assumed & & & -2.369 & 79.142 & .020 \\
\hline Etika & $\begin{array}{l}51 \text { Equal variances assumed } \\
48 \text { Equal variances not assumed }\end{array}$ & 20.555 & .000 & $\begin{array}{l}-5.637 \\
-5.752\end{array}$ & $\begin{array}{l}97 \\
70.526\end{array}$ & $\begin{array}{l}.000 \\
.000\end{array}$ \\
\hline $\begin{array}{r}\text { Kompetensi S } \\
\mathrm{B}\end{array}$ & $\begin{array}{l}51 \\
48\end{array}$ Equal variances assumed & 26.097 & .000 & -7.129 & 97 & .000 \\
\hline & Equal variances not assumed & & & -7.299 & 63.263 & .000 \\
\hline
\end{tabular}




\begin{tabular}{|c|c|c|c|c|c|c|}
\hline \multirow[b]{2}{*}{ Kelompok } & \multirow[b]{2}{*}{$\mathrm{N}$} & \multicolumn{5}{|c|}{$\begin{array}{l}\text { Test for Equality of Uji Beda } \\
\text { Variances }\end{array}$} \\
\hline & & & Sig. & $\mathrm{T}$ & $d f$ & $\begin{array}{l}\mathrm{S} \text { i } \mathrm{g} \\
\text { (2-tailed) }\end{array}$ \\
\hline Paradigma $\mathrm{P}$ & 27 Equal variances assumed & 1.342 & .251 & 3.476 & 73 & .001 \\
\hline $\mathrm{B}$ & 48 Equal variances not assumed & & & 3.719 & 65.133 & .000 \\
\hline \multirow[t]{2}{*}{ Etika } & 27 Equal variances assumed & .561 & .456 & 6.344 & 73 & .000 \\
\hline & 48 Equal variances not assumed & & & 6.610 & 60.834 & .000 \\
\hline \multirow[t]{2}{*}{$\begin{array}{r}\text { Kompetensi P } \\
\mathrm{B} \\
\end{array}$} & $\begin{array}{l}27 \\
48\end{array}$ Equal variances assumed & .089 & .767 & 8.125 & 73 & .000 \\
\hline & Equal variances not assumed & & & 8.135 & 54.226 & .000 \\
\hline & & \multicolumn{2}{|c|}{$\begin{array}{l}\text { Test for Equality of } \\
\text { Variances }\end{array}$} & Uji Bed & & \\
\hline \multirow[t]{2}{*}{ Kelompok } & $\mathrm{N}$ & & & & & $\mathrm{S} \quad \mathrm{i} \quad \mathrm{g}$ \\
\hline & & $\mathrm{F}$ & Sig. & $\mathrm{T}$ & $\mathrm{df}$ & (2-tailed) \\
\hline \multirow{2}{*}{$\begin{array}{r}\text { Paradigma } \\
\mathrm{S}\end{array}$} & 27 Equal variances assumed & 21.909 & .000 & 4.023 & 76 & .000 \\
\hline & 51 Equal variances not assumed & & & 4.987 & 74.012 & .000 \\
\hline \multirow[t]{2}{*}{ Etika } & 27 Equal variances assumed & 15.815 & .000 & 7.711 & 76 & .000 \\
\hline & 51 Equal variances not assumed & & & 9.731 & 71.540 & .000 \\
\hline \multirow[t]{2}{*}{$\begin{array}{c}\text { Kompetensi P } \\
\mathrm{S}\end{array}$} & $\begin{array}{l}27 \text { Equal variances assumed } \\
51\end{array}$ & 14.608 & .000 & 8.966 & 76 & .000 \\
\hline & Equal variances not assumed & & & 11.464 & 69.176 & .000 \\
\hline
\end{tabular}

Sumber : Data sekunder yang diolah, 2013

GAMBAR 1

Kerangka Konseptual Penelitian

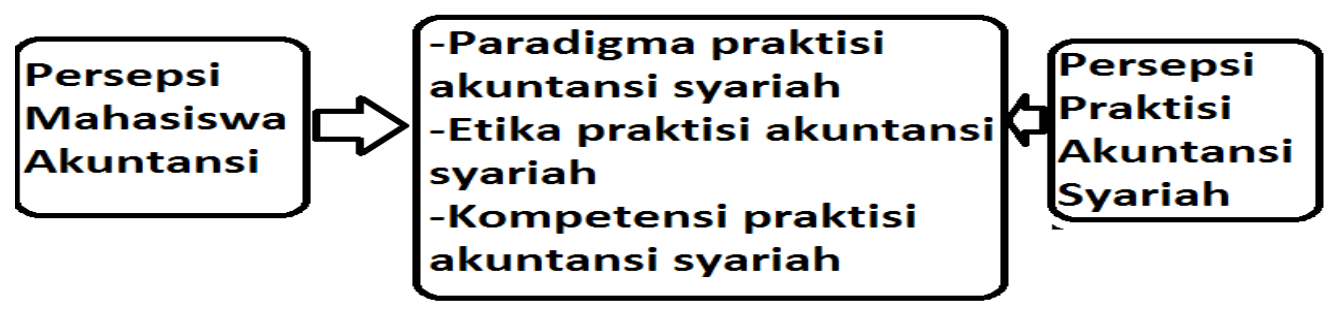

